\title{
Youth Aspirations and Sense of Place in a Changing Rural Economy: The Coos Youth Study
}

\author{
NENA S T R AC U Z Z I
}

\section{Background}

$\mathrm{Y}^{\mathrm{s}}$ oung adults are leaving rural counties as job opportunities dwindle. Coos County, the least populated and northernmost region in New Hampshire, is one such area. Once a region of vibrant communities with a strong middle class earning a living in the paper and pulp industry, the area is now reeling as paper mills permanently shut their doors. The effects are visible, as this mother of a seventh grader in the local middle school says:

"There was more to do when I was younger. The movie theater, for one [and] they had a pool hall, which was a big hangout for us. Then they had a game room, and there were more stores, a lot more stores. Now, the only college we have is the Tech.... [And] what type of jobs can you get around here? Retail? That's pretty much what there is around here. You know?"

As the jobs disappeared, so did the young people, and with them the movie theater, the stores, and the university branch. Between 1990 and 2000, with so many young adults leaving to seek opportunities elsewhere, the county lost nearly 40 percent of its 20-29 year olds (Colocousis, 2008).

The loss of young adults in Coos County has resulted in a significant "graying" of the population. While this is an escalating problem nationwide with Baby Boomers approaching retirement age, it is particularly striking in Coos County in which approximately 19 percent of the adult population is aged 65 or older. Comparable state and national rates are about 13 percent (American Community Survey, 2007). This loss of young people poses a significant challenge for many rural communities. An aging population has greater health care, housing, and transportation needs and demands more institutional care and community service (Kulcsár, 2007; Gittell, 2007). For rural communities already at a disadvantage for lack of service providers, these impending challenges may become an enormous strain, particularly without an adequate pool of young workers.

Moreover, young adults support local schools, they demand quality education, and they contribute to the overall vitality of a community. Youth want to live in an interesting community with a diversity of lifestyles, a stimulating cultural life, a beautiful natural environment, and opportunities for exciting recreational activities (Gittell, 2007; Center for Innovative \& Entrepreneurial Leadership, 2008). Northern New Hampshire is known for its natural beauty and amenity-rich environment, but Coos County has been hard hit by the changing economy, and many communities in the region are simply not as vibrant as they once were. Another mother captures this domino effect:

\section{"The mill closed. That was rough...severance packages helped in the interim, but some nice families have had to relocate. And then the loss of that business has affected other businesses. So the [domino] effect is just going to get worse ...now houses aren't selling....We're [also] worried about the school budget passing...[during one] heated [town meeting discussion] finally parents stood up and said, look, this school is all this town has left. If you want any hope of attracting anybody to move to this place you got to keep a quality school."}

State, local, and community stakeholders are working together to develop community revitalization strategies and reverse the loss of such valuable assets. The Neil and Louise Tillotson Fund of the New Hampshire Charitable Foundation understands the importance of effecting change through well-informed decisions. The Carsey Institute is working with the Charitable Foundation to conduct an extensive research project to understand the ongoing changes in New Hampshire's North Country. One piece of this research includes a ten-year panel study tracking two cohorts of Coos County students who started 7 th or 11th grade in 2007 to examine their attitudes and experiences as they approach adulthood and make critical 
life decisions about education, employment, family, and community. Of particular interest is whether these young people will remain in (or return to) their communities of origin, or whether they will be permanently lured away by better paying jobs in more metropolitan areas.

The goal of the study is to help Coos County practitioners and policymakers work together to find appropriate and targeted solutions. Gaining a better appreciation of the obstacles Coos County students confront in making successful transitions to adulthood is a first step toward this end. Asking young people to talk about these challenges and about the competing objectives they face can offer insights that are lacking in many other studies. Their responses will ultimately help communities retain and attract young working adults.

We introduce our Coos County student respondents in this report. These initial descriptions offer a general sense of who these youth are-their aspirations and beliefs, thoughts and feelings, likes and dislikes, and their concerns over time. As the study unfolds, a more comprehensive story will begin to emerge.

Our study includes 656 students, representing a 78 percent response rate to the initial survey. Researchers consider 78 percent to be a reliable response rate from

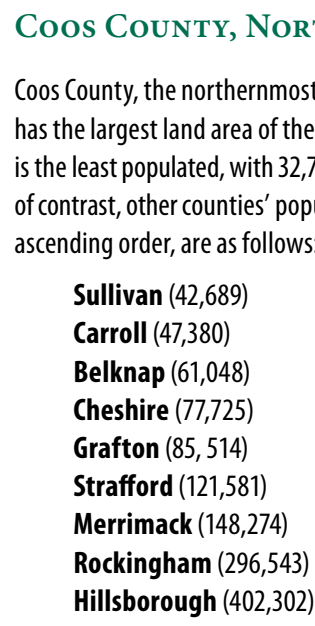

which to draw conclusions. Respondents come from all nine public schools in the county's five school districts. Table 1 presents demographic information, and subsequent graphs further piece together a picture of Coos County youth. Students in Coos are faring pretty well. They are generally positive about their futures - whether they intend to remain in Coos or leave-and are largely satisfied with their family, school, and community relationships. At the same time, just like teenagers everywhere, they are not without their share of problems and concerns, and perhaps more than many, they are very aware of the current economic challenges confronting the North Country and the impact of those challenges on their futures.

\section{Coos County Students' Aspirations for Future Success}

Students of Coos County have high aspirations. According to 2007 data from the American Community Survey (ACS) fewer than 17 percent of all Coos County adults over the age of 25 have bachelor's degrees. The comparable statewide percentage is twice that (32 percent) and nationally, the percentage is 27 percent. Nevertheless, the overwhelm-

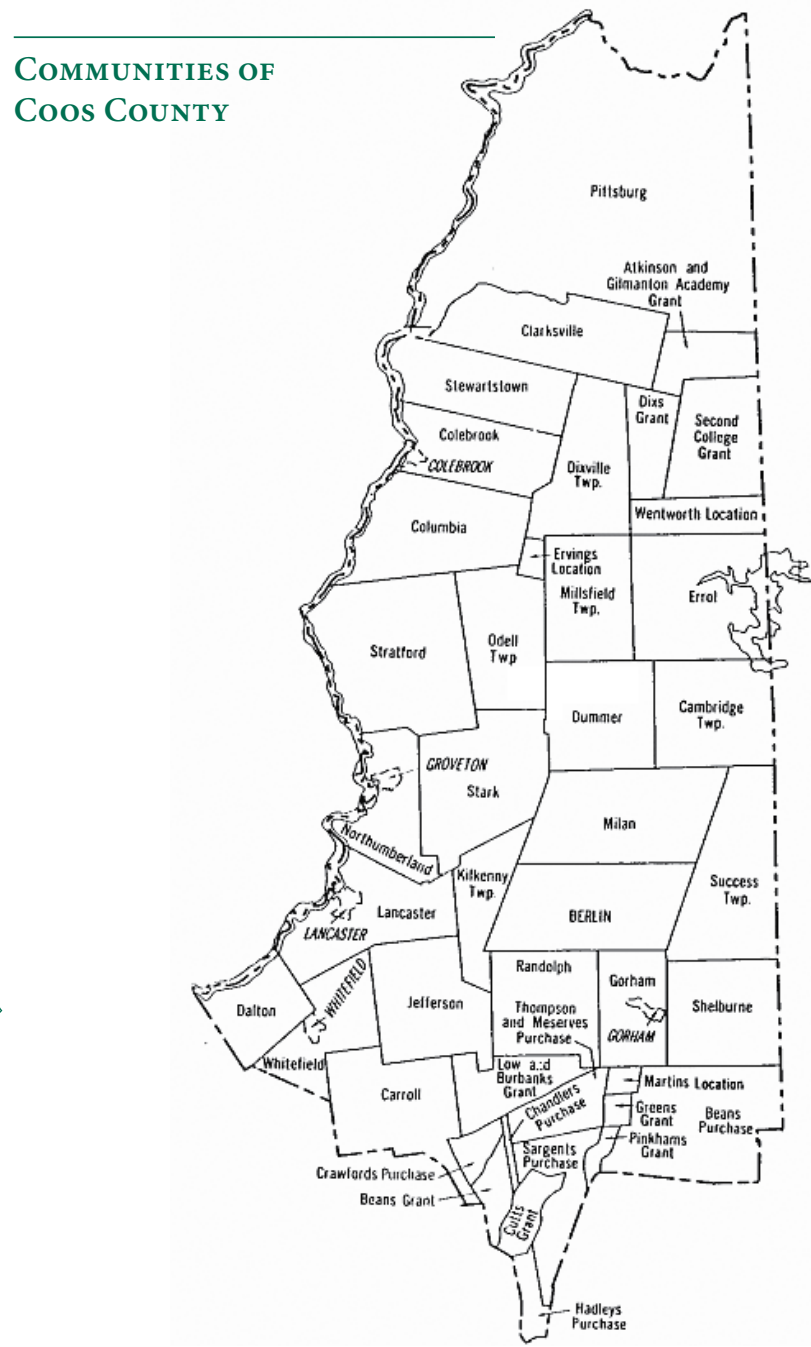


TABLE 1: 2008 DEMOgRAPHICS OF THE 656 COOS Youth SuRVEYed

\begin{tabular}{|c|c|c|}
\hline \multirow[t]{2}{*}{ SEX } & Male & $50 \%$ \\
\hline & Female & $50 \%$ \\
\hline \multirow[t]{2}{*}{ GRADE } & 7th & $48 \%$ \\
\hline & 11th & $52 \%$ \\
\hline \multirow{5}{*}{$\begin{array}{l}\text { SCHOOL } \\
\text { DISTRICT }\end{array}$} & Colebrook & $16 \%$ \\
\hline & Northumberland & $11 \%$ \\
\hline & White Mountain Regional & $32 \%$ \\
\hline & Berlin & $31 \%$ \\
\hline & Gorham & $9 \%$ \\
\hline \multirow[t]{2}{*}{ PAID JOB } & Yes & $57 \%$ \\
\hline & No & $43 \%$ \\
\hline \multirow{3}{*}{$\begin{array}{l}\text { REPORT } \\
\text { CARD GRADES }\end{array}$} & Above Average & $54 \%$ \\
\hline & Average & $31 \%$ \\
\hline & Below Average & $15 \%$ \\
\hline \multirow[t]{2}{*}{ BORN IN COOS } & Yes & $61 \%$ \\
\hline & No & $39 \%$ \\
\hline PARENTS' & Married & $53 \%$ \\
\hline \multirow[t]{3}{*}{ MARITAL STATUS } & Divorced/Separated & $34 \%$ \\
\hline & Never married & $11 \%$ \\
\hline & Widowed & $2 \%$ \\
\hline \multicolumn{3}{|c|}{ FAMILY STRUCTURE } \\
\hline & Two-parent family & $67 \%$ \\
\hline & Both biological parents & $59 \%$ \\
\hline & Stepfamily & $8 \%$ \\
\hline & Single-parent family & $30 \%$ \\
\hline & Mom only & $23 \%$ \\
\hline & Dad only & $7 \%$ \\
\hline & "other" & $3 \%$ \\
\hline
\end{tabular}

\section{PARENTS' EDUCATION}

Less than High School

\begin{tabular}{lr} 
Mom & $6 \%$ \\
Dad & $10 \%$ \\
High School & \\
Mom & $31 \%$ \\
Dad & $44 \%$ \\
Some College & \\
Mom & $23 \%$ \\
Dad & $20 \%$ \\
Associate's Degree & \\
Mom & $13 \%$ \\
Dad & $8 \%$ \\
Bachelor's Degree & \\
Mom & $22 \%$ \\
\hline Dad & $14 \%$ \\
Grad/Prof Degree & \\
Mom & $5 \%$ \\
Dad & $4 \%$
\end{tabular}

TAble 2: Educational Aspirations

\begin{tabular}{|lr|}
\hline Student response & Percent \\
\hline Grad School & $42 \%$ \\
\hline Finish College & $90 \%$ \\
\hline
\end{tabular}

ing majority of students in our study (90 percent) intend to graduate from college, and a sizable minority (42 percent) intend to pursue a graduate or professional degree (Table 2). Coos students are not alone in their high aspirations. Today's students are seemingly aware that the fastestgrowing and best-paying jobs require a college degree. Despite fewer than 30 percent of U.S. adults over 25 years of age with bachelor's degrees, 85 percent to 93 percent of high school students claim they intend to graduate from college, and the majority of those students will enroll in postsecondary education (Alliance for Excellent Education, 2007). Coos County students, like rural teens everywhere, are perhaps painfully aware that options have narrowed significantly for those not attending college.

Unfortunately, aspirations notwithstanding, research also shows that, on average, only about one third of high school graduates are prepared for college. Given this mismatch between students' aspirations and the realities involved in acquiring four-year degrees, many students, particularly those from limited means with limited access to college application information, may be unprepared for the inevitable challenges ahead (Deil-Amen, 2007). These students may be less resilient than those whose aspirations are founded on more realistic expectations and, as a consequence, may be at a much greater risk for dropping out. Policymakers should take note that the most significant hurdle students may face is the misalignment between what high schools provide and what colleges expect academically (Adelman, 2006).

Students' future college and career aspirations are very much in line with what they believe their parents feel is important. The majority of student respondents report for example, that it is very important to finish college (90 percent), get married (75 percent), have children (70 percent), live on their own (76 percent), have a secure job (97 percent), and save money (93 percent). These aspirations align with what students believe is important to their parents as well. Ninety-two percent of students report that their attending college is important to their parents, 75 percent say their plan to marry and raise a family is important to their parents, 96 percent state having a successful career is important to their parents and 94 percent claim their ability to support a family is important to their parents. For both sets of questions, finishing college and having secure and successful jobs score higher than getting married and having children. 
TABle 3: ECONOMIC CONCERNS

\begin{tabular}{|lr}
\hline Student response & Percent \\
\hline Moved to worse neighborhood & $7 \%$ \\
\hline Sometimes hungry & $16 \%$ \\
\hline Parent's employment ended & $17 \%$ \\
\hline Little money available & $23 \%$ \\
\hline Money earned helps to support family & $24 \%$ \\
\hline Hard to find a job & $33 \%$ \\
\hline Saving money earned for college & $43 \%$ \\
\hline
\end{tabular}

\section{Current Family Economic} Conditions

$\mathrm{T}$ he mismatch between expectations and likely reality may be particularly salient for low-income, firstgeneration college students, and may be exacerbated under particularly difficult economic conditions. According to the American Community Survey, in 2004, Coos County had the highest poverty rate in New Hampshire at 10.2 percent. A sizable share of students reported that within the past year, as a consequence of trying economic situations, their lives had been negatively affected (see Table 3). In fact, 16 percent of Coos County seventh and eleventh graders report sometimes going hungry. This is striking given that the state of New Hampshire has one of the lowest rates of food insecurity in the United States. ${ }^{1}$ According to reports from our students, their rate of food insecurity is more than twice the state's average and about 40 percent higher than in the United States as a whole.

First-hand experience appears to leave an indelible mark. A greater share of students whose parents had lost their jobs, believed it would be more difficult for them to find jobs than students whose parents had not lost their jobs (43 percent compared to 30 percent).

\section{Attachment to Community}

$\mathrm{D}$ espite hardships for many, the majority of students were very positive about their communities. Most respondents are happy about participating in community events and are proud of where they live. A relatively high degree of social cohesion is apparent in the extent to which students believe that people can be trusted, that theirs is a close-knit community, and that people are willing to help their neighbors. Further, most believe their communities are safe and that there are many caring and friendly people living there (Table 4).

We ended the questionnaire with two open-ended questions asking students to tell us specifically what they liked most and least about their communities.
Table 4: Social Cohesion

\begin{tabular}{|lr|}
\hline Student response & Percent \\
\hline This is a close-knit community & $56 \%$ \\
\hline Happy to participate in community events & $62 \%$ \\
\hline Proud to present my community & $62 \%$ \\
\hline People can be trusted & $69 \%$ \\
\hline Community is safe & $72 \%$ \\
\hline People are willing to help their neighbors & $74 \%$ \\
\hline People are friendly, caring and helpful & $77 \%$ \\
\hline People get along with one another & $79 \%$ \\
\hline
\end{tabular}

Students refer to their friends, the natural beauty of the area and the closeness of their communities as the things they like most.

It's a good place to teach morals and to raise a family. I like the environment and how it is safe.

It is a very tight-knit community and because it is so small, we get a lot of individual recognition.

[I like] being so close to family and friends-the sense of community and ski areas.

Friends, mountains, rivers, lakes, trees, freedom, forest, space. Lots of outdoor activities.

Everyone unites when times are tough. Tight-knit group.

The environment is more beautiful than any noisy sidewalk and the streets are safe and pleasant.

I like the beauty of the mountains and how nice people are. This is a great place to raise children.

\section{Detachment from Community}

$\Delta t$ the same time, as can be seen in Table 5, most $A_{\text {students also report being bored, that there is not }}$ enough variety in the shops or stores, that people like to gossip, that community members are unduly judgmental and largely unforgiving, and that community members do not seem to care what kids think. A sizable minority feel their community is too isolated and that people are rude, while a fairly small number report too much crime or violence.

The following comments reflect the majority of student responses regarding what they like least:

There's absolutely nothing to do. The elders of the community do not care about the younger population in the slightest. 
TABle 5: Community Concerns

\begin{tabular}{|c|c|}
\hline Student response & Percent \\
\hline Too much crime or violence & $18 \%$ \\
\hline People are rude & $38 \%$ \\
\hline Community feels cut off & $43 \%$ \\
\hline People judge others unfairly & $51 \%$ \\
\hline People do not care about what kids think & $52 \%$ \\
\hline Easy to get alcohol & $66 \%$ \\
\hline Not hard to find drugs & $72 \%$ \\
\hline Nothing to do - it's boring & $72 \%$ \\
\hline Hard to get rid of a bad reputation & $77 \%$ \\
\hline People like to gossip & $79 \%$ \\
\hline Not enough shops or stores & $81 \%$ \\
\hline
\end{tabular}

Being so isolated from other places. Drugs and drinking are common here.

The lack of good jobs; it's pretty much just food or retail.

There is nothing for teens to do. No where to hang out. No good jobs. I wish there was more stuff for kids to do other than drugs.

It's very boring and people are very judgmental of others who are different from them.

A lot of people smoke and drink and do drugs.

In our town, life is not interesting. The same routine, day in and day out becomes monotonous. Many people will remain in this area after high school and oppose new amendments that require taxes. We currently are too poor to afford a new school.

Many youth noted the problem with drugs and alcohol in their communities. More than two-thirds of youth say it is easy to get alcohol or drugs in their community (see Table 5). In our interviews, the students clearly thought this was a problem, particularly the nonchalance of adults involved.

I used to [hang] around with this person. She used to be straight A's and then she went to just failing...because she got into the wrong crowd. She had started dating an [older guy] and he had an ID and he would get her cigarettes and then his dad would get him alcohol and then he would give it to his girlfriend.

I have a friend who...her mom drinks a lot. Like she's a great person when she's not drinking but when she does, she's out of it and that's how my friend started... like she drinks and that's how she started, was from her mom.
Figure 1: No Substance Use in Six Months by Grade
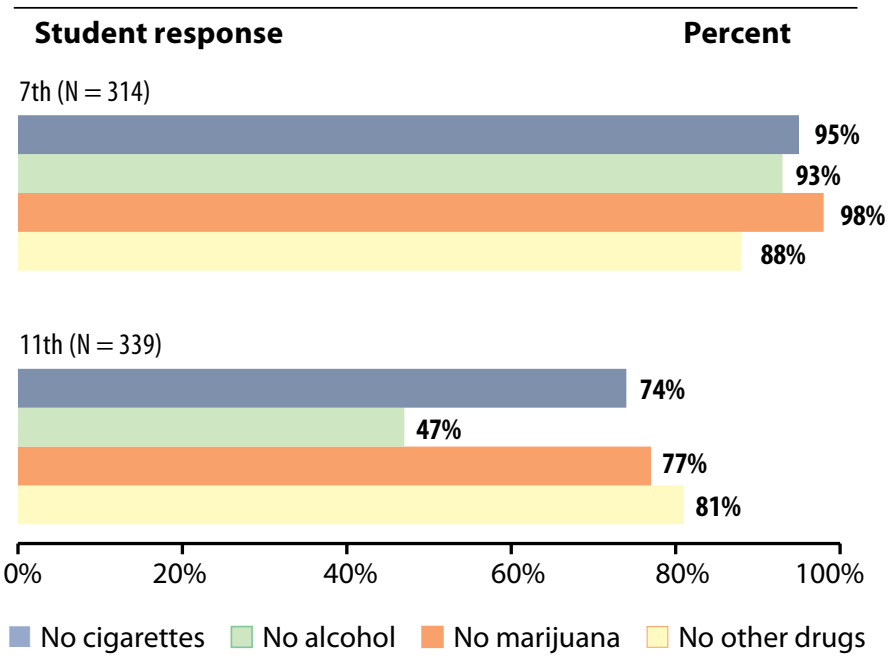

[They go to] friends houses, like the parents will actually like buy them beer and leave it [for them] and [other] kids. I think [that's what] a few do. Because some of the kids drink and then the parents are like, oh, good job not letting [your friend] have [too] many beers...

The majority of students report no alcohol or drug use in the past six months (Figure 1). Rates were particularly low for seventh grade students, with only 2 percent claiming to have smoked marijuana in the past six months and 7 percent having had a drink. Eleventh grade students, on the other hand, reported more substance use. Slightly more than one half (53 percent) of eleventh grade students reported drinking in the past six months. Involvement with other drugs was less frequent. Fully 77 percent of eleventh graders had not smoked marijuana in the past six months.

\section{Emotional Well-being}

Athough students' concerns about their communities A and drug and alcohol problems in particular, are compelling, the majority of students appear to be doing quite well. Their outlooks are generally positive, or perhaps more to the point, they do not have negative outlooks (Figure 2). Most report never feeling lonely, fearful, or depressed; about one half report that on occasion, they may feel sad or unable to get going; and only a minority of students report feeling these emotions frequently or almost all of the time. Unfortunately, though, it is a sizable minority (up to 30 percent in some cases) that reports negative feelings much of the time. It will be important to look closely at these students' life circumstances to determine any noteworthy patterns over time. 


\section{Figure 2: FeElings AND EXPERIENCES IN Past Six Months}
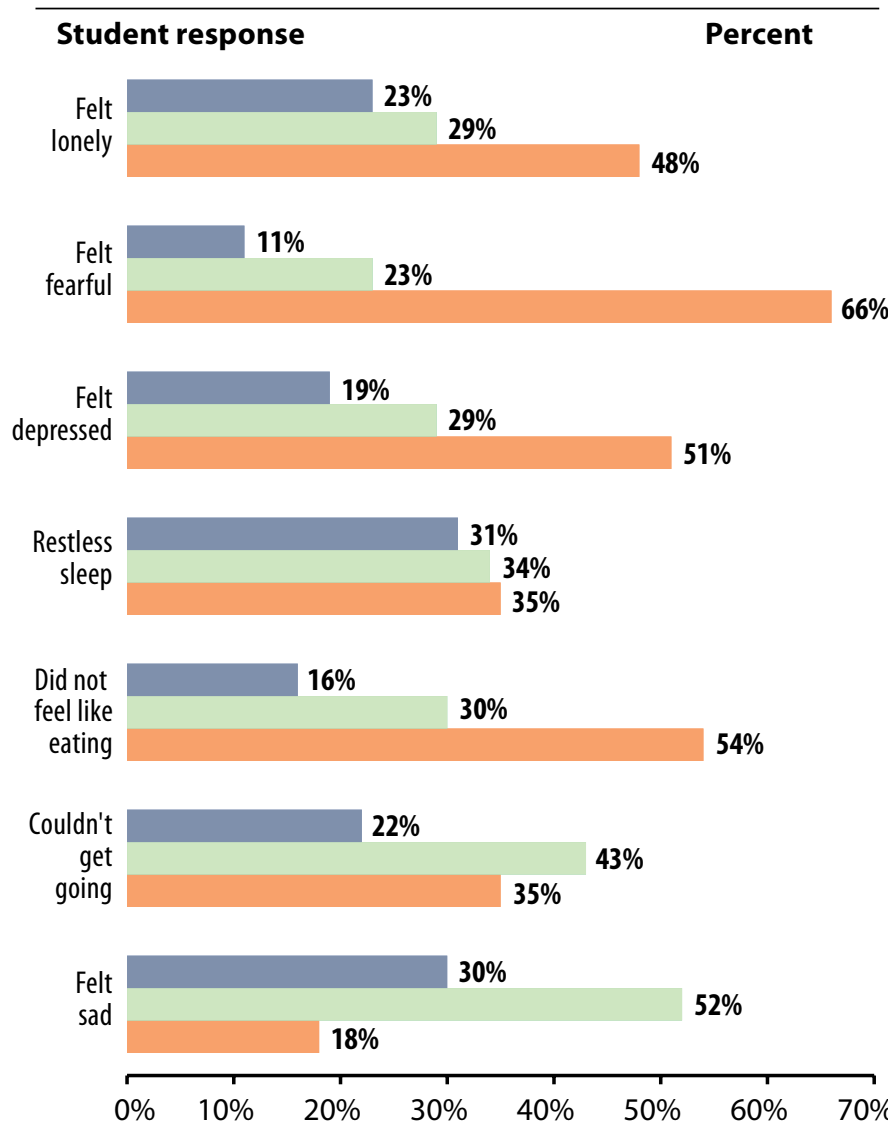

Frequently/most of the time $\quad \square$ 0ccasionally $\square$ Never

Medication - Nearly one in five of our respondents have been prescribed medication for at least one of the symptoms listed in Table 6. Only about one fourth of these teens are represented in the group of students reporting negative feelings much of the time in the past six months. Self-reported diagnoses and types of medication listed indicate that some of the youth who reported problems with their emotions or nerves were being treated for depressive or anxiety disorders. Students who reported taking medication for school and behavioral problems were in most cases being treated for Attention Deficit/Hyperactivity Disorder. ${ }^{2}$

Vulnerability - Findings in Tables 6 and 7 suggest that some student participants may be at risk for depression or other emotional disorders. True disorders in adolescents can be difficult to diagnose because normal adolescence is marked by rapidly fluctuating moods. Reports of feeling badly most of the time in the past six months, however, may be cause for concern. Adolescents who experience negative or stressful life events may be particularly vulnerable to depression and other emotional disorders. Students' whose parents have recently divorced, for example, or who have lost a friend, been in an accident, or been bullied at school,
Table 6: Prescribed Medications

\begin{tabular}{|lr|}
\hline Student response & Percent \\
\hline Difficulties studying & $9 \%$ \\
\hline Problems w/emotions or nerves & $10 \%$ \\
\hline Behavioral problems & $11 \%$ \\
\hline
\end{tabular}

as shown in Table 7, may be even more vulnerable. Students with an accumulation of stressful life events may be at heightened risk.

Resiliency - On the other hand, some students have more protective factors in their lives, which help them to be more resilient than other students facing similar hardships. Studies show, for example, that students with positive and realistic future goals, students who have learned conflict resolution strategies, those who have been encouraged to develop a skill or nurture a talent, or those who have caring adults in their lives may be able to bounce back more easily than students without such supports and attitudes (Center on Adolescence, University of New Hampshire, 2009). Preliminary analyses show a significant relationship between students' reports of feeling depressed

Table 7: Share of Youth Experiencing Negative Life Events in the Prior Year

\begin{tabular}{|l|r|}
\hline Student response & Percent \\
\hline Lost home (natural disaster) & $2 \%$ \\
\hline Home broken into & $4 \%$ \\
\hline Parents asked you to leave & $6 \%$ \\
\hline Move to worse neighborhood/home & $7 \%$ \\
\hline Repeated grade level & $8 \%$ \\
\hline Trouble with law & $11 \%$ \\
\hline Very bad illness & $13 \%$ \\
\hline Parents divorce/separate & $13 \%$ \\
\hline Scared, adults name-calling & $13 \%$ \\
\hline Parent lost job & $17 \%$ \\
\hline Scared, kids name-calling & $22 \%$ \\
\hline Someone's alcohol/drug use causing problems & $24 \%$ \\
\hline Something damaged/ruined on purpose & $25 \%$ \\
\hline Very bad accident/injury & $25 \%$ \\
\hline Something was stolen/not returned & $29 \%$ \\
\hline Hit/attacked on purpose & $29 \%$ \\
\hline Close friendship ended & $32 \%$ \\
\hline Close friend/family member die & $43 \%$ \\
\hline Broke up with a boyfriend or girlfriend & $44 \%$ \\
\hline
\end{tabular}


Table 8: Close Family Relationships

\begin{tabular}{|lr}
\hline Student response & Percent \\
\hline Feel close to another adult, besides parents/guardians & $60 \%$ \\
\hline Feel close to father & $62 \%$ \\
\hline Enjoy spending time with mom & $63 \%$ \\
\hline Feel close to sibling & $68 \%$ \\
\hline Enjoy spending time with dad & $70 \%$ \\
\hline Feel close to mother & $75 \%$ \\
\hline Sibling important & $87 \%$ \\
\hline
\end{tabular}

and being close to someone whose alcohol or drug use is causing problems. Digging a little deeper indicates that factors such as living with married parents, having other caring adults, even playing a musical instrument, among others, seem to moderate the effects of this experience on students' depression.

Just as an accumulation of negative events may increase students' vulnerability, an accumulation of protective factors may lessen that vulnerability. The findings are still preliminary, however, and we cannot make any causal inferences at this point. That said, following the same group of students over time will strengthen our ability to make such inferences. We will then be able to talk more definitively about some of the risk factors that predict more and less successful transitions into adulthood.

One thing we do know from past research is that "tipping the scales from vulnerability to resilience may happen as a result of one person or opportunity." A single family member, a teacher, or a community member can make a difference, despite the adversity a child may face (Benard, 1998:19). Having close family, school, or community relationships may in fact be why most of the students living through at least one stressful event in the past year (Table 7) did not report feeling sad or depressed most of the time in the past six months.

\section{Protective Factors: Family, School, and Community Relationships}

Family - Close family, school, and community relationships may very well be a key reason why the majority of youth, despite a disheartening few, are doing quite well. Table 8 demonstrates that a majority of students consider their siblings to be important and most feel close to them. They also report feeling close to their parents and enjoy spending time with them. A sizable number of students report sharing a special bond with an adult other than a parent, which in the vast majority of cases is a member of their extended family. Other common responses are teachers, neighbors, and coaches.
Figure 3: Assistance with Future Plans

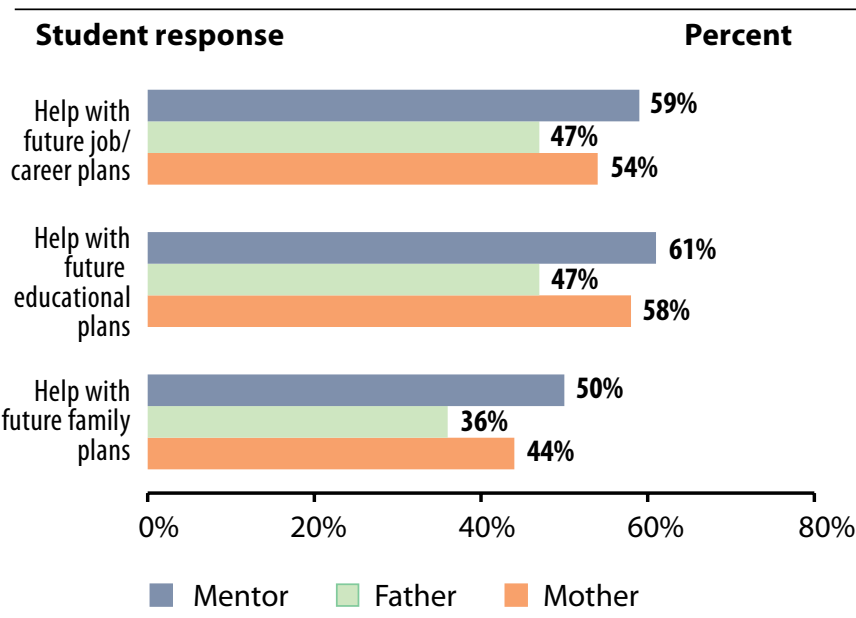

In addition to feeling close to their parents, most students appear to feel confident of having the support they will need to achieve their future goals. More students report being able to count on their mothers than their fathers, and interestingly, students are less likely to anticipate future help from parents than from non-parental mentors. This may be because students do not feel their parents are able to help them, and they seek out someone who is seemingly more knowledgeable (Figure 3).

As one young woman explained during her interview,

"I want to be able to go to college, but I'm not sure if I can pay for it so I want to make sure that I can make it there without having to pay too much. So I'm just working really hard...so that I can go. My aunt's going to help me with [college applications and financial aid] cuz...I don't think my parents know about that, like really know how to go about that."

Most students in the study believe they have at least one parent or other adult they can turn to for help with future plans. Of particular concern, however, are those students who have no one to turn to. As noted previously, students whose college-preparedness does not align with their ambitions may be less likely to graduate from college than those who are more prepared. Tracking these students over time will help us to understand the degree to which a strong support network makes a difference in academic success.

School - Most students report close relationships with their teachers and other students. Most also report that teachers care about their schoolwork, are willing to help them with any difficulties both in and outside the classroom, have set high standards, believe in them, and expect the best (Table 9). This is good news because research clearly demonstrates that "the impact a teacher makes on student learning is tremendous, and high school teachers have much to offer in preparing more students for college" (Alliance for Excellent Education, 2007: 2). 
Table 9: Feelings about SchoOL

\begin{tabular}{|c|c|}
\hline Student response & Percent \\
\hline Students are kind/helpful & $55 \%$ \\
\hline Students enjoy being together & $61 \%$ \\
\hline Teachers care about grades & $76 \%$ \\
\hline Teachers willing to help with personal problems & $76 \%$ \\
\hline Students accept me & $78 \%$ \\
\hline Teachers care whether I do my work & $79 \%$ \\
\hline Teachers help outside of class & $83 \%$ \\
\hline Teachers expect the best & $90 \%$ \\
\hline Teachers believe I can do well & $92 \%$ \\
\hline
\end{tabular}

Students whose teachers set high standards and have high expectations may be better prepared for college. In order to maintain high expectations however, and deliver on them, teachers must be able to make content accessible to a wide range of learners (Alliance for Excellent Education, 2007). To date, students genuinely feel their teachers believe in them and have set high standards for them; only time will tell whether those students are more likely to succeed than others.

Students also largely report that other students accept them, are kind and helpful, and enjoy being together at school. This is not true for everyone, however. Nearly one quarter of students reported not feeling accepted by others, more than one third reported that students do not enjoy being together, and slightly less than one half feel that other students are unkind or unhelpful (Table 9).

Findings from the first round of analyses suggest that the extent to which students feel they are accepted by other students may have implications for their emotional well-being as well as their educational accomplishments. This line of inquiry will be examined in greater depth in further analyses.

Community and Friends - As Table 4 revealed, social cohesion is high, with most teens reporting that they live in a tightly knit community and that people get along with one another. Nearly every student had a good group of friends in their communities, reported that other kids think they are fun, reported receiving many invitations from other kids to do things, and indicated that they spend a lot of time with others teens on weekends. They also report spending more face time than virtual time online with friends. Regardless, Coos County students' use of the Internet appears only slightly lower than teens nationally. Findings are not directly comparable however, as the most recent available national data are from 2006.

A Pew Internet and American Life Survey found that in 2007, 93 percent of teens used the Internet, 89 percent of teens reportedly using it at home, and 75 percent using it
TABle 10: Friends and Cyber Friends

\begin{tabular}{|lc|}
\hline Student response & Percent \\
\hline FRIENDS & \\
\hline Spend lots of time with kids on weekends & $75 \%$ \\
\hline Kids think I'm fun & $80 \%$ \\
\hline Lots of invitations from kids & $82 \%$ \\
\hline Good group of friends in my community & $90 \%$ \\
\hline
\end{tabular}

\section{CYBER FRIENDS}

\begin{tabular}{|l|c|}
\hline Lots of text messages from kids & $38 \%$ \\
\hline Lots of e-mail from kids & $41 \%$ \\
\hline Lot of networking messages (eg, myspace) & $58 \%$ \\
\hline Lots of instant messages from kids & $58 \%$ \\
\hline
\end{tabular}

at school. In 2008, 87 percent of Coos teens reported using the Internet, with 88 percent reporting using it at home and 90 percent using it at school. The Pew report also finds that more teens used the Internet as a setting for social interaction in 2006, with 68 percent using instant messaging, 55 percent having a profile on a social networking site such as Facebook or MySpace, and 49 percent playing online games. In 2008, 63 percent of Coos teens reported using instant messaging, 60 percent visited a social networking site, and 47 percent played online games.

It appears that Coos County students are not being left completely in the dark, so to speak, when it comes to the digital world, although their slightly lower use is consistent with past research showing that rural areas tend to lag behind other areas in digital access and use (Hiemstra, 2005). As it happens, broadband access to the Internet in the North Country has not yet reached peak capacity, which may be why use is slightly lower than national rates. It may also be why many students report feeling frustrated with their Internet connections. Thirty percent of Coos County students are frustrated daily with the slow speed of their Internet connection, and that percentage increases to more than one half ( 52 percent) when asking whether they were frustrated at least once per week. Approximately one third of Coos teens report being unable to access the Internet at all at least once each week; 16 percent of students report being unable to obtain access on a daily basis.

Teens in the North Country may not be completely up to speed when it comes to Internet access, though most are nevertheless actively engaged in the digital world. This will be another interesting theme to follow over time as digital access improves in northern New Hampshire. Fortunately, for most participants, they are still spending ample time with friends in person. 


\section{Extramural Activities}

At School - In addition to spending time on their computers, students engage in a variety of activities both at school and outside school. Table 11 shows all activities in which students report being engaged. In school, students were most active in sports, with nearly three-fourths involved in some sport. Roughly one half of teens reported being engaged in art, about one third were in band, and nearly one fourth were in theater, academic clubs, honor society, and hobby clubs. We also asked students about the availability of each of these activities. In large part, very few students reported no access to these activitiesfewer than 10 percent in most cases, except for student government (11 percent), academic clubs (14 percent), and hobby clubs (11 percent). The least common activity was the school yearbook or newspaper, with only 13 percent involved. Eight percent of kids however, reported these options were unavailable to them.

Outside of School — Students also report being involved in a number of activities outside school. Not surprisingly, youth reported "hanging out" more frequently than other

\section{Table 11: Extramural Activities}

\section{Student response}

Percent

\section{ACTIVITIES AT SCHOOL}

\begin{tabular}{ll} 
School yearbook or newspaper & $13 \%$ \\
\hline Student government & $17 \%$ \\
\hline Hobby clubs & $20 \%$ \\
\hline Honor society & $20 \%$ \\
\hline Theatre & $23 \%$ \\
\hline Academic clubs & $24 \%$ \\
\hline Band/choir/music & $33 \%$ \\
\hline Art & $52 \%$ \\
\hline Sports & $72 \%$
\end{tabular}

\section{ACTIVITIES OUTSIDE OF SCHOOL}

\begin{tabular}{lc|}
\hline YMCA or teen center & $3 \%$ \\
\hline $4 H / S c o u t s$ & $10 \%$ \\
\hline Community service & $24 \%$ \\
\hline Church groups & $25 \%$ \\
\hline Volunteering & $35 \%$ \\
\hline Community events & $56 \%$ \\
\hline Outdoor activities & $77 \%$ \\
\hline Hanging out & $93 \%$
\end{tabular}

TABLE 12: Other ACtivities

\begin{tabular}{|lr|}
\hline Student response & Percent \\
\hline Travel & $1 \%$ \\
\hline Art & $2 \%$ \\
\hline JROTC & $2 \%$ \\
\hline Student council & $2 \%$ \\
\hline Afterschool program & $2 \%$ \\
\hline Hanging out & $2 \%$ \\
\hline Partying & $3 \%$ \\
\hline Family & $3 \%$ \\
\hline Music & $3 \%$ \\
\hline Mentoring program & $4 \%$ \\
\hline Video games & $6 \%$ \\
\hline Work & $9 \%$ \\
\hline School activities & $12 \%$ \\
\hline Sports & $12 \%$ \\
\hline Outdoor activities & $35 \%$ \\
\hline
\end{tabular}

activities, but outdoor activities were also very popular, as were community events. A significant minority of students (35 percent) report volunteering, and 25 percent report being engaged in church groups and community service. Fewer students report being involved with $4 \mathrm{H}$, Scouts, the YMCA, or teen centers, with a sizable minority of students reporting that these activities are unavailable. In particular, 24 percent of our respondents say that YMCA or teen centers are unavailable, 9 percent say that $4 \mathrm{H}$ or Scouts are unavailable, and 12 percent say no community service activities are available.

Other Activities - Students were allowed to add activities to the list with which we presented them, and 188 students did so (Table 12). We have attempted to categorize the responses, although students' actual responses are more interesting. In terms of outdoor activities, for example, students included four-wheeling, hunting, biking, horseback riding, skiing, skateboarding, and snowboarding. Additional school activities included helping special education children, student council, afterschool programs, student leadership programs, world language club, and youth mentoring. Other responses included paintball, family activities, playing drums, baking, shopping, video games, flying a plane, just chillin', working on cars, and a few items not fit for print. 


\section{Stay or Go?}

Come of the difficulties confronting young people in Coos $\checkmark$ County are evident in the data presented above. Many are bored, concerned about the economy, worried about jobs, and troubled about the extent of drug and alcohol use. They also seem to feel that adults are gossipy and judgmental and do not care about what youth think. Further, a significant number of students report feeling sad, lonely, and depressed most of the time, and a considerable percentage reported emotional, behavioral, and attention problems. Sixteen percent of participants reported going hungry on occasion because their family could not afford food, and 25 percent use their own money to help support their families.

That said, the bulk of the evidence clearly demonstrates that most of Coos County's 2007 seventh and eleventh grade students are doing well, despite some of the difficulties they face. Their aspirations are high, and they report positive family, school, and community relationships. They are engaged in numerous and varied activities and spend significant time with other kids. They love the natural beauty of their surroundings and the closeness of community members. Regardless, more than one half of students (52 percent) report they are unlikely to remain in their communities most of their lives, and more than one third (37 percent) report they are likely to leave their communities and never return (Table 13). At the same time, 60 percent of students report feeling that it is important to live near their families as adults, which implies that students are conflicted. Students who were interviewed in person commented on this issue insofar as their own futures are concerned.

"I want to come back here [after college]," said one 12-year-old girl. "Like some people say they just want to get out. Well, when you think about it for a sec, if you ever need something here, you know everybody, like we do and you can just call somebody up and you'll know there's somebody there. Whenever you need something, whether it be you need a new door or like [help with your] mental health, there's some[body]...I like it up here. It's kind of comforting...I don't' know, I just like it here. It's a small town type thing. I can't do cities. I'm not good with crowds. And I want my kids to grow up in a small town."

In contrast, this 12-year-old girl said,

"I can't think of a reason to come back [after college]. People probably do come back, like some people. But...I can't think of a reason why they would come back-unless they're in the lumber industry. But also the lumber industry is dying too. I picture myself someplace else, definitely. I will visit here because my mom will probably still be in this house...but for now I'm thinking I'm going to [live] somewhere else. There's nothing here-our economy is dying almost, and we're not doing very good. I don't know, it's just...we're too small."
Table 13: Desire to Remain in Community

\begin{tabular}{|lr|}
\hline Student response & Percent \\
\hline Likely to leave community and never return & $37 \%$ \\
\hline Unlikely to spend most of their lives in area & $52 \%$ \\
\hline Important to live near family & $60 \%$ \\
\hline
\end{tabular}

These contradictory responses illustrate the competing objectives confronting today's Coos County students. According to survey and interview findings, these responses also clearly capture what many students are facing in developing their future plans. By following students' trajectories over the next ten years, we have the extraordinary opportunity to discover the extent to which students' aspirations are realized. Perhaps more important, for those students who reach their goals against the odds, we will be able to ascertain the types of protective factors that can help them to be more resilient when confronted with the types of adversity so many Coos County students have experienced in recent years. Ultimately, our objective is to learn about the combination of factors that seem to predict more and less successful transitions into adulthood as well as those that can tell us why some young adults are more likely to stay in the area and some more likely to leave. The extent to which community factors may be responsible will be of great interest to policymakers as they work to develop strategies to persuade young adults to return to, and re-invest in, the North Country.

\section{E N D NOTES \\ 1 New Hampshire's rate of household food insecurity is $7.4 \%$ while the national rate is $11.3 \%$, according to the U.S. Department of Agricul- ture. Food insecurity is defined as being uncertain of having, or being unable to acquire enough food for all household members because of limited resources. Those considered to have very low food security also reported times of disrupted eating patterns and reduced food intake. Mark Nord, "Characteristics of Low Income Households with Very Low Food Security: An Analysis of the USDA GPRA Food Security Indicator," Economic Information Bulletin. (Washington, DC: USDA, Economic Research Services, 2007), available at www.ers.usda.gov/ Publications/EIB25/ (retrieved January 5, 2008).}

2 Percentages shown in Table 6 are substantially higher than national averages for ADHD. The Center for Disease Control (CDC) estimate that roughly 5 percent of children aged 6 to 17 have ADHD. This rate may not be directly comparable, as our estimates are from students' self-reports. However, to the extent that students' self-reports are accurate, it would appear that ADHD rates among Coos County students are higher than the average rates reported by the CDC. See CDC, Diagnosed Attention Deficit Hyperactivity Disorder and Learning Disability: United States, 2004-2006: Data From the National Health Interview Survey (Atlanta: Centers for Disease Control, DATE), available at http://www.cdc.gov/nchs/data/series/sr_10/Sr10_237.pdf (retrieved 12/2/2008). 


\section{BINGE DRINKING}

There is potential cause for concern regarding the extent of drinking among those reporting alcohol consumption in the past six months. Thirteen percent of students report typically drinking one to four drinks and approximately $17 \%$ report having more than five drinks when they drink. About one half of those students (8\%) report consuming more than nine drinks whenever they drink. According to national surveys on drug use and health in 20052006 , binge drinking is defined as drinking five or more drinks on the same occasion (i.e., at the same time or within a couple of hours of each other) on at least one day in the past 30 days. The national rate of binge drinking in the past month among youth between ages 12 and 17 was $10.1 \%$ in 2006 (down from $10.5 \%$ in 2005).

Number of Drinks Typically Consumed When Drinking (LAst Six Months)

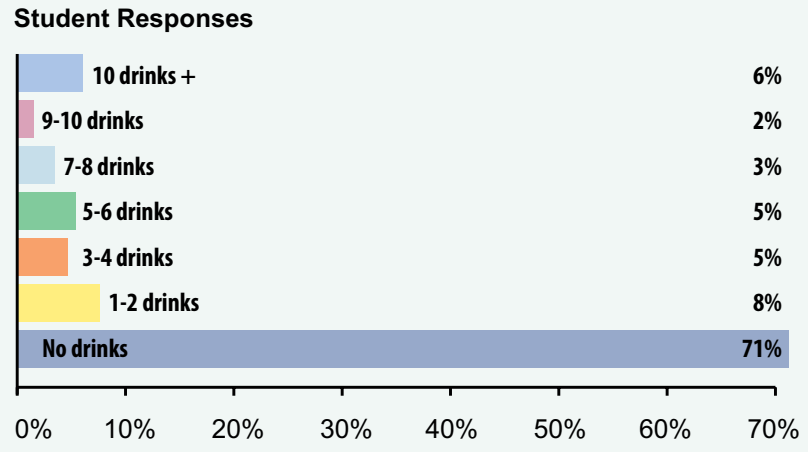

Past research shows that excessive drinking may be a serious problem among rural youth, particularly in homes where parents are absent. Excessive use may stem from perceptions that heavy drinking is more often considered normal in rural America. In 2003, for example, youth in rural areas were less likely than their urban counterparts to report that binge drinking was risky (36\% versus $39 \%$, respectively; differences were small but statistically significant). Thirty-one percent of rural young adults believed that binge drinking was not risky behavior; $44 \%$ of adults felt the same way (Van Gundy, 2005).

\section{R E F E R E N C E S}

Adelman, Clifford. 2006. The toolbox revisited: Paths to degree completion from high school through college. Washington, DC: U.S. Department of Education. http://www.ed.gov/rschstat/research/pubs/toolboxrevisit/ toolbox.pdf

Alliance for Excellent Education. 2007. High school teaching for the $21^{\text {st }}$ century: Preparing students for college. Issue Brief, September. Washington, DC: Alliance for Excellent Education. http://www.all4ed.org/files/HSTeach21st.pdf

Benard, Bonnie. 1998. Fostering resiliency in kids: Protective factors in the family, school, and community. National Resilience Resource Center. http://www.cce.umn.edu/pdfs/ NRRC/Fostering_Resilience_012804.pdf

Colocousis, Chris, 2008. The state of Coos County: Local perspectives on community and change. Issue Brief no. 7. Durham: University of New Hampshire, Carsey Institute.

Center for Innovative \& Entrepreneurial Leadership. 2008.

The community vitality initiative (CVI). http://www.theciel. com/cvi.php

Deil-Amen, Regina. 2007. When aspirations meet reality for low-income minority high school students in their transition to college. Paper presented at the Annual Meeting of the American Sociological Association, August 11-14, New York City. http://www.allacademic.com//meta/p_mla_apa_ research_citation/1/8/4/3/5/pages184359/p184359-2.php

Gittell, Ross. 2007. The declining young adult population in New England. Fact Sheet no. 1. Durham: University of New Hampshire, Carsey Institute.

Hughes, Arthur, Neeraja Sathe, and Kathryn Spagnola. 2008. State estimates of substance use from the 2005-2006 national surveys on drug use and health. DHHS Publication no. SMA 08-4311, NSDUH Series H-33. Rockville, MD: Substance Abuse and Mental Health Services Administration, Office of Applied Studies.

Kulcsár, Laszlo. 2007. Baby boomers and immigrants on the range: Population trends in Kansas. Kansas Policy Review, 29 (1). http://www.ipsr.ku.edu/publicat/kpr/kprV29N1/ kprV29N1A1.shtml

Lenhart, Amanda, et al. 2007. Teens and social media: The use of social media gains a greater foothold in teen life as they embrace the conversational nature of interactive online media. Washington, DC: The Pew Internet \& American Life Project. http://www.pewinternet.org/PPF/r/230/report_ display.asp

Van Gundy, Karen. 2005. Substance abuse in rural and small town America. Reports on Rural America, 1 (2). Durham: University of New Hampshire, Carsey Institute. 


\section{A U T H O R}

Nena Stracuzzi is an assistant research professor at the Carsey Institute.

\section{A C K N OW L E D GEM E N T S}

The Coos Youth Study Team is indebted to the Neil and Louise Tillotson Fund of the New Hampshire Charitable Foundation and the Carsey Institute for supporting this research. The authors thank all the students who are participating in this research project and those thirty moms who so graciously allowed us into their homes to conduct face-to-face interviews with them as well as their teens. We would like to thank all superintendents, principals, guidance counselors and administrators from each of the five school districts: John Moulis, Bev Dupont, DeDe Aube, Gary Bisson, and Ken Proulx from Berlin (SAU\#3); Robert Mills, Priscilla McGuire, Mark Ekberg, Lydia Johnson and Dawn Petit from Colebrook (SAU\#7); Paul Bousquet and Keith Parent, from Gorham (SAU\#20); Lou Lafasciano, Roxanne Hartlen, Richard Hartford, Frank Mellaci, Ryan Earley, Janet Steinert, Jean Jacobs, Cecile Currier and Deb Fogg from White Mountain Regional (SAU\#36); and Carl Ladd, Pierre Couture, Pat Kelly, Mary Jolles from Northumberland (SAU\#58). Each of them helped our research team collect these data as seamlessly as was humanly possible. We would also like to thank Cathy McDowell from the Family Resource Center in Gorham for introducing us to Coos County's Superintendents and always being available to lend an ear and offer advice. Thank you to Michele Dillon, Jennifer Esala, Mil Duncan, and Curt Grimm for reading early drafts of this brief and providing feedback. And finally, for their valuable editorial assistance and suggestions to the final piece, we thank Cesar Rebellon, Barbara Ray, and Amy Sterndale. We want to especially thank Bridget Farmer for always going above and beyond her job description and providing invaluable assistance at every stage.

\section{THE CARSEY INSTIT UTE}

\section{COOS YOUTH STUDY}

The Carsey Institute is conducting a panel study of Coos County youth that will provide data about the attitudes and experiences of the county's youth as they approach young adulthood and face the decision to remain in their community, seek opportunities elsewhere, or leave for an education and then return. By following the entire populations of two age groups over a ten-year period, we will help North Country leaders gain a better understanding of young people's decision making.

\section{R ESEARCH TEA M}

Cesar Rebellon is a Carsey Institute Faculty Fellows and Associate Professor of Sociology. His primary research interests focus on family and peer correlates of juvenile crime and delinquency with a particular emphasis on the manner in which delinquency may yield reinforcing social rewards among adolescents.

Nena Stracuzzi is Assistant Research Professor at the Carsey Institute. Her research at the Carsey Institute has been focused on vulnerable youth and families.

Corinna Jenkins Tucker is a Carsey Institute Faculty Fellow and Associate Professor of Family Studies. Her primary research interests focus on adolescents' family relationships.

Heather Turner is Professor of Sociology and Senior Fellow at the Carsey Institute.

Karen VAn Gundy is a Carsey Institute Faculty Fellow and Associate Professor of Sociology. Her work investigates the mechanisms by which life circumstances and social statuses influence variations in health, emotional, and behavioral outcomes.

Bridget FArmer, Research Assistant, is a dual major in political science and international relations at the University of New Hampshire and an undergraduate research assistant at the Carsey Institute.

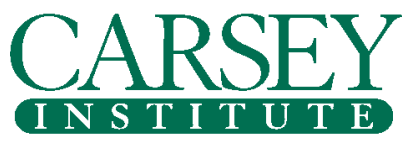

Building knowledge for families and communities

The Carsey Institute at the University of New Hampshire conducts independent, interdisciplinary research and communicates its findings to policy makers, practitioners and the general public.

Carsey Institute Reports on Tracking Change in the North Country are supported by the Neil and Louise Tillotson Fund at the New Hampshire Charitable Foundation and the Carsey Institute endowment.

Huddleston Hall

73 Main Street

Durham, NH 03824

(603) 862-2821

www.carseyinstitute.unh.edu 